\title{
Local Business Climate in Ghana - Insights for Policy Direction
}

\author{
Mavis Serwah Benneh Mensah \\ School of Business, University of Cape Coast \\ Cape Coast, Ghana
}

Tel: 233-245-093-600 E-mail: mbenneh@yahoo.com

Received: August 15, 2011

Accepted: September 13, 2011

Published: January 16, 2012

doi:10.5539/ijbm.v7n2p17

URL: http://dx.doi.org/10.5539/ijbm.v7n2p17

\begin{abstract}
This study provides insights for enhancing the business climate in Ghana. The primary objective of the study was to identify the most relevant binding constraint(s) on the activities of micro, small and medium-sized enterprises (MSMEs) in the manufacturing sector of Sunyani Municipality and Berekum District of Ghana. Accordingly, a survey of 85 manufacturing MSMEs was conducted. In spite of energy crisis in Ghana at the time of research, the most relevant binding constraints to the enterprises surveyed were poor access to technology including technological support services, and poor access to market (which will be discussed in subsequent paper). The findings contradict policy focus on addressing governance and regulatory bottlenecks, and inadequate physical infrastructure. This underscores the importance of local business climate surveys in addition to national surveys in establishing the right policy focus for enhancing the business climate of localities within a country.
\end{abstract}

Keywords: Business climate, Most relevant binding constraint(s), Governance, Infrastructure

\section{Introduction}

Today, business climate issues are at the forefront of development agenda of nations. Business climate, or what is commonly referred to as investment climate in development literature, reflects the many location-specific factors that shape the opportunities and incentives for firms to invest productively, create jobs, and expand (The World Bank, 2004). Governments, development cooperation partners and world economic bodies have since the 1990s collaborated in diverse ways to promote sound business climates for specific economies as well as the global economy. An economy is said to have a sound business climate when it dwells on stability and openness in economic and political policies; efficient, transparent and effective governance and regulatory systems; and availability of the required infrastructure that support economic activities to grow and thrive. A sound business climate encourages investments and entrepreneurship needed for growth and development.

Businesses that operate in an enabling environment are highly predisposed towards attaining substantial, consistent and sustainable decrease in cost of operation, and increase in productivity and profitability. With good returns on investments, businesses, their employees and society gain in several ways. Increases in shareholder value, wages and salaries, employment avenues and tax revenue for infrastructure development are some of the benefits of a sound business climate. Consumers also benefit from availability of quality and affordable goods and services. All of these advantages translate into improved standard of living for the masses and with time, the growth and development of businesses is expected to collectively translate into economic growth and development of respective nations. Similarly, the growth and development of nations is expected to collectively translate into growth and development of the world economy.

Egypt is one of the few countries in Africa that has a business climate development strategy (BCDS) and the country is receiving payoffs for its efforts. In 2009, Egypt was selected for the fourth consecutive time as a Top 10 Reformer by the World Bank Doing Business Report. In the same years Egypt achieved record rates of GDP growth while its job creation improved exceeding 3 percent growth per annum (OECD, 2010). The success story of CzechInvest, an investment promotion agency (IPA) of the Czech Republic is also commendable. CzechInvest is noted for its expertise in investment promotion and provides training and expertise to other investment promotion agencies. This was made possible through adoption of best practices such as facilitating generation of investments by providing useful business information to prospective investors as soon as they need it (OSCE, 2006). 
The government of Ghana has been partnering the World Bank and Deutsche Gesellschaft für Technische Zusammenarbeit (GTZ) GmbH, now under the umbrella body, Deutsche Gesellschaft für Internationale Zusammenarbeit (GIZ) GmbH to identify key business climate issues for policy direction. The Association of Ghana Industries' (AGI) annual investment climate surveys and the World Bank Doing Business Report have been key instruments that inform their decisions. This is indeed a good initiative. Nonetheless, World Bank Doing Business Report takes a national perspective which limits its usage for regional and local policy direction. The AGI's annual investment climate survey is gradually overcoming the drawback of limiting the survey to the capital city of Ghana, Accra. Based on the two instruments, addressing governance and regulatory issues and development of physical infrastructure have been the focus of national reform policy. Generally, macro or country level policy and governance reforms, and development of physical infrastructure are prerequisites for strengthening the investment climate for private sector-led growth (Mbaku, 2003; Jackson, 2004) otherwise deep institutional weaknesses such as corruption will certainly reduce economic growth, retard long-term foreign and domestic investments, and enhance inflation (Akcay, 2006). However, it has been argued whether better infrastructure and an improved legal environment are themselves sufficient to reach a quantum leap in private investment in Africa (Asche, 2006; see also Sachs et. al, 2004). Consequently, this paper seeks to contribute an answer towards the discussion.

The study was conducted primarily to contribute towards the identification of the right policy focus for improving the business climate of Sunyani Municipality and Berekum District of Ghana. Accordingly, it was designed to achieve three key objectives: (a) to identify business climate factors that were relevant to the activities of privately owned manufacturing MSMEs in Sunyani Municipality and Berekum District; (b) to assess and establish the state of the identified business climate factors from the perspective of entrepreneurs of the MSMEs; and (c) to establish which business climate factor(s) was/were the most relevant binding constraint(s) on the activities of the MSMEs for policy attention.

The paper is divided into five main sections including the introduction. The next section is a presentation of some key theoretical and conceptual issues of business climate studies under the limitation that business climate is an evolving research area, particularly in Ghana. This is followed by presentations of methodology, results and discussion, and conclusions and policy implications respectively.

\section{Theoretical and Conceptual Issues}

As an evolving field of research, business climate is one of the concepts of development that has lent itself to several definitions and explanations. The variety of definitions notwithstanding, a cursory look at a number of them (Lall \& Mengistae, 2005; The World Bank, 2004; Hallward-Driemeier, Wallsten \& Xu, 2003; and The World Bank, n.d.) indicates uniformity in what business climate stands for. Business climate encompasses three broad categories of issues or factors. These are macro or country-level issues; governance and institutions; and quality and quantity of physical, financial, and technological infrastructure.

Macro or country-level issues dwell on stability and openness in terms of national public policies which affect the degree of political and economic stability and the extent to which the country is integrated into the global economy. Examples of business climate factors under this first category are macroeconomic, fiscal, monetary, trade and exchange rate policies and political stability. Sound macroeconomic policy is cited as an issue demanding immediate attention in Sub-Sahara Africa (Belshaw \& Livingstone, 2002). According to Belshaw and Livingstone (2002), failure to follow sound macroeconomic policies has produced serious shortages of foreign exchange, shortage of imported materials and huge excess capacity in the enterprises set up. In addition, trade liberalisation and complete removal of government subsidies is a strongly debated macro level policy issue. One school of thought strongly supports complete liberalisation of trade in Sub-Sahara Africa (SSA) since it is believed that this will pave way for growth and development of the continent (Miles 2006). On the other hand, it is believed that developing countries need some degree of protectionism to enable domestic enterprises thrive in the face of competition (Stiglitz \& Charlton as cited in Miles, 2006; see also Arthur, 2003).

The second category of business climate factors - governance and institutions- relates to the functioning of rule of law, that is, efficacy of the regulatory framework. The World Bank implores governments of developing countries to be committed to good governance since aid given to countries with good institutions and policies has a far higher likelihood to affect growth positively than aid given to countries of poor institutions and policies (Ovasko, 2005). Again, the World Bank (n.d.) puts forward a very important question on the issue of regulations: whether regulations are 'designed in incentive compatible ways, avoid adverse selection and moral hazard, serve the public interest, are implemented expeditiously without harassment and corruption, and facilitate efficient outcomes' (The World Bank, n.d., p. 20). Moreover, Dasai and Pradham (as cited in Batra, Kaufmann \& Stone, 2003) reiterate that investment climates around the world suffer from a 'crisis of governance' and that bad investment climates do not just happen, they are made - not because public officials lack the knowledge and 
expertise to govern well, but because there are deeper imbalances in ways policies are designed and implemented. According to them, these distortions consist of bribes, cost of 'patron-clientelism' and 'state capture'.

The third category of investment climate factors relates to infrastructure. This includes access to physical, financial and technological infrastructure such as reliability and efficiency of power supply, transportation, telecommunications, banking and finance and the endowment of skills and technology. This third category is deemed a key determinant of competitiveness and profitability (The World Bank, n.d.). The Africa Action Plan (AAP) is one of the instruments of the World Bank which guides it in implementing decisions on Africa, especially with regard to Official Development Assistance (ODA). The AAP has among its priorities closure of the infrastructure gap and improving governance in Africa (The IMF \& the World Bank, 2007).

All three categories of business climate factors have tremendous effect on growth and development of a nation through facilitation or hampering of productivity and profitability of private sector activities. As can be inferred from the preceding discussion, several propositions have been made for policy focus in improving the business climate of countries in SSA. However these propositions fail, to a greater extent, to recognise the specific conditions of the various countries in SSA and seemingly treat all countries as facing similar constraints. For instance, it is said that there are three main barriers to SME growth in Africa - deficient public utilities, especially erratic power supply; an unpredictable business environment including insecure property rights, contract enforcement difficulties and corruption; and limited access to much-needed capital as well as basic banking facilities (Siddiqi, 2006; Versi, Nevin, \& Ford, 2005).

It is important to note that for investment climates, there are differences among countries as well as differences among locations within countries (The World Bank, 2004). As such, a continent-wide approach to identification of constraints for policy attention is not likely to yield effective and efficient outcomes. Besides, it is noted that recommendations for tackling the identified issues are made on wholesale basis. Wholesale recommendations are hardly possible to implement considering resource constraints that face policy makers and implementers. Policies achieve little or nothing at all when policy makers are presented with 'a laundry list of needed reforms and have either tried to fix all of the problems at once or started with reforms that were not crucial at given times to the country's growth potential. In such a situation, reforms, more often than not, have gotten in each other's way, with reform in one area creating unanticipated distortions in another area' (Hausmann, Rodrik \& Velasco, 2006, p. 13). There is an inevitable truth behind the humour in Hausmann, Rodrik and Velasco's (2006, p. 13) call on countries to identify the one or two most binding constraints on their economies and then focus on lifting those 'Rather than use a spray-gun approach in the hope that we will somehow hit the target...'

In identifying the most relevant binding constraint(s), entrepreneurs - very important stakeholders in the economic sphere - have proven to be a vital source of information. Jackson, (2005) adds his voice to the call for identification of relevant binding constraints. He recommends that 'what is perhaps needed is a proper evaluation of constraints, as well as the opportunities within the sub-continent, particularly from the perspective of managers who operate in Africa and how these are addressed through the strategies of organisations' (2005, p. $61)$.

On this premise, some lessons can be drawn from the few researches that have so far been conducted on business climate factors of concern to this study - specifically governance and regulatory issues and infrastructure. Operationalisaton of business climate variables has seen some degree of uniformity over the years. In assessing the impact of the investment climate on productivity of three South American countries, Escribano and Guasch (2005) measured the business climate in terms of infrastructure, bureaucracy/corruption, crime, and finance. Infrastructure variables included power outages and duration, losses due to power outages, phone interruptions and wait for phone, days to clear customs for imports, among others. Bureaucracy/corruption was measured by inspection days (by tax inspectorate, labour and social security, etc.), percentage of time spent dealing with regulations, payments to deal with bureaucracy 'faster', fraction of sales undeclared to the IRS. Losses due to crime as a percentage of sales and number of criminal attempts suffered are variables used to measure crime. Overdraft, loan, and constrained access to loan were used to measure access to finance (The World Bank, 2004).

In 2003 the World Bank launched the Doing Business Report in 130 countries, including Ghana. Business climate dimensions covered in the Report included business registration, insolvency, contract enforcement, and accessing credit. The main variables used to measure the dimensions are number of procedures and time to complete them, and fees and costs associated with compliance. Similar lessons could also be drawn from the World Bank's Investment Climate Surveys which were launched in 2001 with 55 participating countries. The main dimensions used in these surveys are regulations, governance, access to finance and physical infrastructure. Variables for these dimensions are both objective - time to complete processes and monetary costs of various disruptions and regulations - and perceptive - potential constraints and assessments of risks and competition - in nature (The World Bank, 2004). Periodic investment climate surveys by the Association of Ghana Industries 
(AGI) use dimensions and variables similar to those of the World Bank's Investment Climate Surveys. The AGI national investment climate survey is a multi-sector survey with 300 respondents. The manufacturing sector accounts for 60 percent of respondents of the survey. The 2007 survey ranked constraints with the first five as follows: national load shedding exercise programme, competition from imported goods, cost of credit, quality of power supply and access to credit.

As informed by these surveys and recommendations from development partners, recently, Ghana's economic reform policy has mainly centred on championing good governance and development of physical infrastructure. It is acknowledged that good governance and availability of adequate and quality physical infrastructure are necessary requirements for spurring more and profitable private sector investments needed for growth and development. Nonetheless, it has been questioned (for example, Asche, 2006, Sachs et al., 2004) whether current focus on governance and physical infrastructure improvements is sufficient enough to attain higher investments needed to propel growth and development in Africa. This paper contributes an answer to this query.

From the preceding discussions, researchers identify three broad categories of business climate factors - macro or country level factors, governance and institutions, and infrastructure. A major reality is that these factors are numerous and in the face of resource constraints, countries, in their bid to improve their investment climates, need to focus on the one or two most relevant binding constraint(s) at a time for effective and efficient outcomes. Moreover, entrepreneurs or managers serve as an important source of information in the identification of the most relevant binding constraint(s). Furthermore, several recommendations have been made for improving the business climate in SSA. A key concern which this paper seeks to address is that the current focus on governance and regulatory issues, and development of physical infrastructure as areas demanding immediate attention to promote growth and development in most African countries, including Ghana, may not hold, especially for all economic locations within a country.

\section{Methodology}

The study was guided by a combined research design, specifically the mixed methodology design (Creswell, 1994). The purpose of adopting this design was to add breadth and scope to the research findings. Another purpose was to use the qualitative aspect of the study to inform the quantitative part. Therefore, in addition to pilot-testing and implementing the survey instrument, institutional interviews were conducted.

The study group comprised a total of 227 private sector manufacturing MSMEs in Sunyani Municipality and Berekum District in the Brong Ahafo Region of Ghana. In addition, the enterprises were at least two years into operation and employing a minimum of two full-time workers. The population was so defined because the manufacturing sector is considered an important strategic driver to Ghana's agriculture-led economic growth. In addition, economic activities in Ghana are largely controlled by participants in the private sector making the sector an important engine for growth and development. Moreover, it is believed that MSMEs have higher potential to grow and make significant contributions to economic development and employment generation (see Smallbone \& Wyer, 2006). For instance, it is estimated that small and medium enterprises (SMEs) provide about 85 percent of manufacturing employment of Ghana. Moreover, SMEs contribute about 70 percent to Ghana's GDP and account for about 92 percent of businesses in Ghana (Abor \& Quartey, 2010). Consequently, addressing constraints facing MSMEs will make them more productive and thus raise the value of their contributions to GDP. The age and employment 'limits' were necessary in ensuring that businesses had some experience in employment creation and local business climate issues for a study of this nature.

Definitions of business size by the National Board for Small Scale Industries (NBSSI) and by the Regional Project on Enterprise Development (RPED) in Ghana were adopted. Both definitions used employment as a distinguishing factor - micro enterprises employ one to five people while small enterprises employ between six and 29 people. Medium Enterprises employ 30 to 99 people. The sampling frame was derived from the most recent national industrial census (2003-2004/2005) database secured from the Ghana Statistical Service and crosschecked with data compiled by the researcher in October 2006. The study sample was 95 which represented 34 percent of the study population. Respondents were selected through proportionate stratified sampling in the following order - first, on the basis of the two study locations (Sunyani Municipality and Berekum District) to arrive at sample size for each location; second, by manufacturing sub-sectors (wood, metal, textile, structural, and soap and related products) in each study location to arrive at sample size for each sub-sector; and third, by random selection of respondents in each sub-sector. Respondents comprised enterprise owner-managers, and hired managers where management was not in the hands of the owner.

The questionnaire method was used to collect data with more than 90 percent response rate -85 valid questionnaires were received. This was made possible due to commitment to field preparation, pretesting the instrument and administration of the questionnaires. An important aspect of the preparations was the mapping 
out of the two study locations into zones which aided in the efficient and effective identification of respondents at their business premises. As a result of low literacy level of majority of the respondents, the instrument was administered by the researcher and two field assistants. Administration of a questionnaire, on the average, lasted between twenty and thirty minutes. The interviews took place at the work place of the respondents where privacy was assured. Two weeks to the main data collection exercise, the questionnaire was tested on 22 respondents. The exercise lasted five days. At the close of each day, results were collated and the necessary changes made to the instrument.

The constructs, corresponding variables and indicators evolved through interaction with entrepreneurs during the preliminary survey. This was buttressed with lessons from literature especially the 2005 World Development Report on investment climate indicators and guidance from firm-level questionnaire on the business climate for manufacturing enterprises of the World Bank's Enterprise Analysis Unit. The final questionnaire was made up of 37 questions categorised under firm background information, access to market, inter-business linkages, and investment climate measures.

This paper presents findings on the investment/business climate. For infrastructure, variables of concern that emerged were access to utilities, business and technological services, and finance. Tax administration, provision of public services/licenses and incidence of bribery in the provision of the services and in the acquisition of public contract came up as governance issues of concern (see Appendix II for background information and investment climate sections of the questionnaire). Road network and transportation matters were not captured in the main survey since during the preliminary study, respondents considered road network in the study locations as well as in the Brong Ahafo Region as generally good. Also respondents did not view transportation as a problem.

Three institutional interviews were conducted on taxation, and business and technological support services to buttress the findings. The institutions included the Internal Revenue Service (IRS) at Berekum, the National Board for Small Scale Industries (NBSSI) at Sunyani and the Business Advisory Centre (BAC) at Berekum. The data was analysed with SPSS version 13.

\section{Results and Discussion}

This section of the paper is a presentation of sample characteristics and main research findings on the local business climate. The study focused on the last two categories of business climate factors - governance and regulations, and infrastructure - since the experiences of entrepreneurs did not go beyond these as informed by a preliminary test.

\subsection{Characteristics of the Sample}

Sample characteristics captured in the study included business size, age, registration, legal status and sub-sector operation (see Table 1). A greater percentage ( 80 percent) of MSMEs sampled was micro enterprises. The mean age was 13 years with the trend of business establishments somehow depicting periods of Ghana's economic upturns and downturns and associated government policies. For example, from 1957 to the early 1970s, state policy supported massive industrialisation through state owned enterprises (SOEs); therefore, the private sector saw few entrants over the years. Economic downturn in the late 1970s and in the 1980s could also explain the low level of business establishments in the region. Recovery of the economy from the 1990s and efforts of governments to involve the private sector in building the economy may be an underlying factor in the steady rise in business establishments over that period. Sixty six percent of the MSMEs operated as sole proprietorships. Less than half of the MSMEs sampled (31 percent) had their businesses registered. This indicates that, in Ghana, registration of business before commencement of operations is not a strict requirement particularly for sole proprietorships.

\section{Insert Table 1 here}

\subsection{The Local Business Climate}

Key findings on the local business climate are presented on the basis of the research objectives. In line with research objective one, business climate factors which according to entrepreneurs were relevant to their activities related to governance and infrastructure including infrastructure service provision. For these two constructs, the variables of concern that emerged for infrastructure and infrastructure service provision were access to utilities, business and technological services, and finance. Tax administration, provision of public services/licenses and incidence of bribery in the provision of the services and in the acquisition of public contract were governance issues of concern. These factors were individually studied to derive answers to the second research objective which sought to establish the state of identified business climate factors that entrepreneurs considered relevant to their activities. The concluding paragraphs of this sub-section consist of review and brief discussion of findings 
on research objective two and research objective three which aimed at identifying the most relevant binding constraint(s) on the MSMEs. Descriptive statistics, basically mean, standard deviation and percentages, were used to analyse data.

Utilities of concern included telephone, water and electricity (see Table 2). None of the MSMEs either had internet connection at business premise or utilised commercial internet service points for business transactions. The most used utility was telephone service ( 90 percent for landline telephone and mobile phone services) followed by power supply with 81 percent of premises connected to the public grid. In contrast, connection of business premises to public water supply system was the least acquired utility (22 percent). Users rated landline telephone service as having low price (mean score of 2.7), public water supply, mobile phone service and electricity supply as having moderate prices with mean scores of 3.1, 3.2 and 3.4 respectively.

\section{Insert Table 2 here}

Quality of utility supply was assessed on the basis of interruptions, or otherwise, in service provision, for example, power cuts, fall in quantity or voltage, etc. (see Table 2). The mean scores show that users deemed the quality of all utility supply as average (with landline telephone service and electricity supply having relatively higher mean scores of 3.6 and 3.5 respectively). With mean scores of 2.0, 2.2 and 2.5 for landline telephone, electricity and water respectively, respondents conveyed the message that they experienced interruptions once in a month at their business premises (which they interpreted during the preliminary study as rare).

\section{Insert Table 3 here}

For business and technological support services, access was evaluated on the basis of awareness, usage, quality, affordability and frequency of use of services. The study focused on services that were relevant to business operations of the MSMEs. The services included training, information provision and equipment development provided by both public and private institutions. The findings revealed that not many entrepreneurs (42 percent) were aware of the availability of support services and not all who were aware of the services utilised them (29 percent had used services before), in spite of good ratings for quality and affordability of services by users (Table 4). On the average, users rated business and technological support services received as quality (mean score of 2.3) and free of charge (mean score of 1.3). They made occasional use of the services, basically, one to three times a year.

\section{Insert Table 4 here}

From the experiences of entrepreneurs, the leading purpose of use of business and technological services was to secure finance and management assistance either from service providers or with the assistance of the service providers. For example, the Business Advisory Centres (BACs) of the National Board for Small Scale Industries (NBSSI) played facilitation role to users in accessing development funds such as the International Fund for Food and Agricultural Development (IFAD). It was observed that BACs were the most frequented service providers followed by financial institutions and technology centres. In addition, some MSMEs received paid services from large enterprises. This was particularly the case of the wood sub-sector where processes that could not be performed due to lack of requisite equipment, were sub-contracted to larger enterprises that had the equipment.

In relation to governance and regulations, the MSMEs considered acquisition of public services and licences, award of public contracts, and taxation as issues that immediately related to their activities and with which they had some level of experience. The most commonly demanded public services included business registration or acquisition of operating licence, construction permit, electricity, water, and landline telephone connection. Timeliness of the provision of these services was tested by establishing delays (and their duration), if any, in acquiring such services. With the exception of application for construction permit, all services on the average were provided within one to four weeks after application - that is, mean scores varying from 1.5 to 2.2 (Table 5). Connection of business premise with landline telephone recorded the least delay in service provision - a minimum of 2 weeks for full connection to be done. Eighty percent of registered enterprises registered and/or obtained licence to commence business within one to four weeks, that is, seven to 31 days. Correspondingly, publication by the World Bank Group in its Doing Business Reports indicated that number of days for starting a business in Ghana have reduced over the years from 81 in 2006 and 2007 to 42 in 2008 and to 34 in 2009 . Bribery as a condition for receiving fast service was also tested by establishing whether officials of service providers (all public entities at the time of research) expected a gift (bribery) before service was provided.

\section{Insert Table 5 here}

In relation to the incidence of bribery in the acquisition of public services, no entrepreneur indicated that a gift (bribery) was expected before service was provided or bribe had to be paid to acquire a public contract. However, 11 percent of respondents who had won public contracts before claimed they had part of their contract payments 
(between 1-5 percent of contract payments) unofficially withheld. According to the respondents, in some instances, official receipts were issued for such deductions for income tax while others simply believed they were cheated.

On taxation, 88 percent of MSMEs surveyed made official payments to government revenue collection institutions, while 12 percent did not. The main types of payments included artisan fee paid by artisans, council levy and Value Added Tax (VAT). Entrepreneurs spent below one percent of management time per week on tax administration issues - a probable indication that entrepreneurs had much time to see to other business matters. In terms of affordability of payments as dictated by the financial ability of each enterprise, MSMEs on the average considered the amounts paid as moderate - mean score of 3.6 - although getting close to high. Consistency in tax interpretations implies the consent or otherwise of entrepreneurs with the statement that 'interpretations of tax regulations affecting one's business are predictable and consistent'. On the average entrepreneurs agreed, to some extent (mean score of 2.3), with the assertion that tax interpretations were consistent and predictable. The overriding issue behind this finding was the lack of consultation between the revenue collection institutions and entrepreneur groups (such as business associations) in establishing new tax rates. According to the entrepreneurs, they were usually not given prior notice of tax increments and implementation date. The IRS however attributed the information gap to entrepreneurs' failure to follow public announcements on taxes in the media.

Access to finance is an important business climate factor for establishing how sound or poor a given climate is. The main sources of business capital (operating capital) within the previous two years were internal funds/retained earnings, bank credit/overdraft and trade credit accounting for 47 percent, 20 percent and 20 percent respectively. Credit from local and foreign commercial banks and development assistance funds administered through banks was further assessed. In general, 26 percent of MSMEs had access to bank credit within the preceding two years. All loan beneficiaries had to provide some form of collateral. The mean score of 2.5 in Table 6 indicates that, on the average, loan beneficiaries were required to use their work machinery as collateral.

On the average, loan beneficiaries received between approximately $\mathrm{GH} \phi 700$ and GH $\phi 800$ (currently, a Cedi exchanges for 1 Dollar at approximately GH\&1.5) - equivalent to mean score of 5.5 (Table 6). The relatively high standard deviation score of 2.2 calls for further elaboration on loan amounts received. Of the total credit beneficiaries, 45 percent received between less than $\mathrm{GH} \phi 100$ and up to $\mathrm{GH} \phi 699 ; 15$ percent had between $\mathrm{GH} \notin 700$ and GH $\notin 1000$, while 45 percent received above GH\&1000. With the mean score of 1.6, loan beneficiaries had up to less than one year (technically six months) to repay the loan received. Interest rate, on the average, varied between 16-20 (approximately equal to mean score of 4.4) percent per annum. Thirty seven percent of entrepreneurs had applied for credit facility with the bank but were unsuccessful mainly due to inadequate collateral, bureaucratic and procedural constraints and unfavourable repayment terms.

\section{Insert Table 6 here}

Upon this premise, a synopsis and brief discussion of findings for research objective two and three are necessary. The second research question sought to establish the state of the identified factors from the perspective of the entrepreneurs while the third aimed at establishing the most relevant binding constraint(s) of the MSMEs. First, the results indicate that on the average, entrepreneurs who used utilities for business activities considered all utilities as affordable and of average quality with rare interruptions in supply. In spite of energy crisis in Ghana in the year of survey, entrepreneurs rated electricity supply as average in quality as 'industrial' zones and clusters were spared frequent power cuts through power rationing. This finding contradicts that of the 2007 (closest year for comparison) AGI national investment climate survey which ranked the national load shedding exercise programme as the number one constraint.

Although connection of business premises to public water grid was on the lower side, enterprises whose activities demanded connection of premises to public water supply had water at their premises (Table 3). Activities such as manufacture of soap, cement and clay products required enough water at all times at work premises and accordingly all enterprises in these sub-sectors had water at their business premises. The remaining questionable sub-sector is the food processing sub-sector whose enterprises should practically have had water supply at business premises. However, more than 70 percent of food processing enterprises was into maize drying and packaging which did not require use of water in large quantities. Another important physical infrastructure that could have cost implications on the activities of enterprises, especially transportation of raw materials and finished goods, is road network. In the preliminary survey, respondents considered road network in the Brong Ahafo Region as quite good and not a constraint to their activities. 
Consequently, in line with research objective three which focused on identifying the most relevant binding constraint to the activities of the MSMEs, access to utilities was not a most relevant binding constraint. This implies that the much-talked-about major constraint to SME growth in Africa - deficient public utilities - spotted in most business climate literature (for example, Siddiqi, 2006; Versi, Nevin \& Ford, 2005) is not substantiated by this study which was conducted at the local business climate level. This buttresses the caution by the World Bank that for business climates, there are differences among countries as well as differences among locations within countries (The World Bank, 2004).

Second, with the exception of application for construction permit, which on the average lasted between two to four months, applications for other public services went through within one month. Moreover, the average number of entrepreneurs who paid taxes reckoned the affordability of the payments as moderate and spent less management time on tax administration issues. In all, it can be said that there was low incidence of bribery. With the exception of taxation and receipt of payment for the execution of public contracts which recorded very low incidence of bribery and corruption, there was no incidence of bribery associated with acquisition of public services such as business registration. Business registration had recently been decentralised. This, entrepreneurs believed, was the source of sanity in the system and reason for the shorter average registration period of four weeks. Likewise, bribery associated with taxation was almost non-existent among the entrepreneurs due to the system of collection - there was collective collection of taxes for business associations. This does not by any means imply that the collective collection exercise dealt with bribery and corruption since there was no information on the existence of bribery before inception of the collective collection of tax from association members. Similarly, the 2007 (the closest year for comparison) AGI national investment climate survey did not record any governance and regulatory issue among the top five constraints.

In relation to research objective three, the foregoing analysis and discussion substantiate the fact that governance and regulations were not the most relevant binding constraints to the MSMEs surveyed contrary to the prevailing stance (see the IMF \& the World Bank, 2007; Siddiqi, 2006; Versi, Nevin \& Ford, 2005). An issue that could obscure support for this finding is the low number of registered businesses. Bureaucratic inefficiencies are ruled out as a reason that deterred enterprises from registering their businesses because 80 percent of enterprises that registered their businesses or acquired operating licenses did so in one month with no reported cases of bribery. In Ghana, business registration is not a strict requirement for commencement of business activities especially for sole proprietorships. With the majority of respondents operating as sole proprietorships (78 percent), the MSMEs, therefore did not see the need to register and constantly pay renewal fees, unless registration was a prerequisite for bank loan application.

Third, access to financial infrastructure was low. This corroborates what several literature and business practitioners present as a major constraint to business activities in Africa. For example, the results of the 2007 AGI national investment climate survey indicated 'cost of credit and access to credit' among the top five constraints. However, in this study it cannot be deduced with much certainty that poor access to finance was a major binding constraint on activities of entrepreneurs. It is common knowledge, as also gathered through discussions with respondents, that poor access to finance is a result of the high risk factor of lending to MSMEs. Most often, MSMEs are unable to invest borrowed funds and have good returns on the investment within a reasonable period, pay back the borrowed funds, and even on time. This risk factor is usually associated with many micro enterprises in Ghana. In fact, 80 percent of the MSMES sampled were micro enterprises and 66 percent operated as sole proprietorships. In addition, the average age of these enterprises was 13 years and 31 percent had their businesses registered (a major means of establishing the formal-informal status of businesses in Ghana is by official registration of business). Altogether, financial institutions interpret these facts as lack of enough business experience and basis for ineffective performance and therefore refuse to lend to such MSMEs.

Fourth, it is believed that ability of entrepreneurs to secure needed funding is highly dependent on availability of relevant and adequate business and technological support services. From the research findings, entrepreneurs' access to business and technological support services in the study region was poor. In addition, awareness and usage of services relevant to the activities of enterprises were low in spite of good rating by users for quality of service received. A key finding of the institutional interviews is that organisations that provided business and technological support services were not well-equipped and financially resourced to offer needed support to entrepreneurs. In the face of scarcity of needed support services, entrepreneurs resorted to what they could afford - simple tools and equipment - and their own ingenuity and experiences thereby limiting their ability to perform well. For instance, most enterprises (64 percent) had their customer base limited to the Brong Ahafo Region with 54 percent recording poor business performance in the previous year (see Benneh, 2007). Consequently, it can be inferred from the discussion that the most relevant binding (business climate) constraint for the MSMEs was poor access to business and technological support services. 


\section{Conclusions and Policy Implications}

The primary objective of this research was to identify and assess the most relevant binding constraint(s) of MSMEs with respect to the local business climate. The major findings of the study are a departure from the commonly acclaimed bottlenecks of governance and regulations, and poor and inadequate physical infrastructure facing the small business sector in Africa. Here are some key findings of the study. First, access to utilities was, on the average, fairly good with users rating utilities demanded as affordable and of average quality. Second, analysis of findings on governance and regulatory issues, relevant to the activities of the MSMEs surveyed, shows that these business climate factors are in quite good state. Third, the MSMEs had poor access to the required business and technological support services. This limited their ability to perform well and secure the necessary funding.

Business and technological support is so critical to the ability of MSMEs in meeting customer expectations, expanding their market base, and increasing sales and profitability. As a result, although access to finance was poor, it is inferred, based on the analysis and discussion of findings, that it is a result of lack of creditworthiness of the MSMEs. Thus, the much-talked-about major constraints to SME growth in Africa, specifically deficient public utilities, poor governance and regulations and poor access to finance spotted in most business climate literature were not directly and entirely substantiated by this study which was conducted at the local business climate level. As a result, in terms of the local business climate, poor access to business and technological support services was the most relevant binding constraint facing the MSMEs surveyed.

It will therefore be a step in the right direction for economic policy of the study region to give prime attention to the development of business and technological support services for the small business sector. Moreover, in spite of quite good state of other business climate factors studied, it is important to ensure continuous improvement of these factors since a recline in the quality of these factors could have serious economic ramifications on businesses and the economy as a whole. Of particular importance is the need to solve power fluctuations associated with electricity supply. Furthermore, there is the need for close and constant collaboration and dialogue between revenue collection institutions and the MSME sector to deal with the perceived information asymmetry and the seeming lack of input of the MSME sector in establishing new tax rates.

The study makes two key contributions to the literature on business climate. First, local business climate surveys are as relevant as national business climate surveys since marked differences could exist between the national and local business climates. The reality is that, studies conducted at the global, regional, continental and national levels are very useful for generating knowledge about which factors to investigate. However, it is local studies that will clarify the specific and unique factors at play in each locality. The appreciable difference between the findings of this study and that of the 2007 AGI national investment climate survey underscores the importance of local surveys to determine justifiable direction for local economic policies. This implies that sole reliance on national business climate surveys for the development and direction of local economic policies and plans could be misleading and unproductive. Second, the study indicates the importance of in-depth study of business climate factors as against mere ranking of factors as constraints. An in-depth study is a means of providing sufficient evidence or otherwise for general perceptions on the business climate. For instance, in the year of survey, a key finding (based on ranking) of the AGI national investment climate survey was that the power rationing exercise was generally perceived as the number one constraint of manufacturing enterprises nationwide. However, the findings of this study shows otherwise for the local business climate surveyed.

Future research may therefore look at factors that contribute to the marked differences in the national and local business climates. It is observed that in spite of the high relevance of business and technological support services to the activities of enterprises, it is usually not spotted among the list of major constraints presented in most national and continental (specifically Africa) business climate literature. The 2007 AGI national investment climate survey of Ghana is an example. This raises several questions - do the samples of such national surveys constitute more medium and large enterprises that do not require the services of business and technological support organisations? Alternatively, are the kinds of services required by medium and large enterprises offered by organisations other than those that serve MSMEs? Consequently, do organisations that serve medium and large enterprises not encounter the challenges that those which serve the MSME sector face? These questions including in-dept study of the nature of business and technological support for enterprises in Ghana could be focus of future research.

\section{References}

Abor, J., \& Quartey, P. (2010). Issues in SME development in Ghana and South Africa. International Research Journal of Finance and Economics, Issue 39 (2010), 218-228. [Online] Available: http://www.eurojournals.com/irjfe_39_15.pdf (February 10, 2011). 
Akcay, S. (2006). Corruption and human development. Cato Journal, 26(1), 78. [Online] Available: http://www.questia.com/PM.qst?a=o\&d=5014900457 (July 6, 2007).

Arthur, P. (2003). The implications of state policy for micro-enterprise development. In W. J. Tettey, K. P. In W. J. Tettey, K. P. Puplampu \& B. J. Berman (Eds.). (2007). Critical perspectives in politics and socio-economic development in Ghana (pp. 153-175). Leiden, Netherlands: Brill. [Online] Available: http://www.questia.com/PM.qst?a=o\&d=109306612 (May 9, 2007).

Asche, H. (2006). The World Bank's Africa Action Plan: new actions? Bonn: Deutsches Institut für Entwicklungspolitik. German Development Institute GmbH.

Association of Ghana Industries. (2007). 2007 National investment climate survey. (June 30, 2007) [Online] Available: http://www.agighana.org/business_environment/agi_bc_surveys/index.php

Batra, G., Kaufmann, D., \& Stone, A. H. W. (2003). Investment climate around the world: voices of the firms from the World Business Environment Survey. Washington, D. C.: World Bank.

Belshaw, D., \& Livingstone, I. (2002). Renewing development in Sub-Saharan Africa: policy, performance, and prospects. London: Routledge.

Benneh, M.S. (2007). Local business climate and market access - the case of micro and small-sizedmanufacturing enterprises in Sunyani municipality and Berekum district of Ghana. Master Thesis. University of Leipzig.

Creswell, J.W. (1994). Research design: Qualitative and quantitative approaches. London: Sage Publications.

Escribano, A., \& Guasch, J. L. (2005). Assessing the impact of the investment climate on productivity using firm-level data: methodology and the cases of Guatemala, Honduras and Nicaragua. Washington, D. C.: World Bank. [Online] Available: http://wwwwds.worldbank.org/external/default/WDSContentServer/WDSP/IB/2005/06/28/000112742_2005062 8085042/Rendered/PDF/wps3621.pdf (June 5, 2007).

Hallward-Driemeier, M., Wallsten, S., \& Xu, L. C. (2003). The investment climate and the firm: firm-level evidence from China. Washington, D. C.: World Bank. [Online] Available: http://wwwwds.worldbank.org/external/default/WDSContentServer/WDSP/IB/2003/04/11/000094946_0304010 4075327/Rendered/PDF/multi0page.pdf (May 20, 2006).

Hausmann, R., Rodrik, D., \& Velasco, A. (2006). Getting the diagnosis right: A new approach to economic reform. Finance \& Development, 12-15.

Jackson, T. (2004). Management and change in Africa: A cross-cultural perspective. New York: Routledge. [Online] Available: http://www.questia.com/PM.qst?a=o\&d=107516232 (July 6, 2007).

Lall, S. V., \& Mengistae, T. (2005). Business environment, clustering, and industry location: evidence from Indian cities. Washington, D. C.: World Bank. [Online] Available: http://www.nmcc-vikas.gov.in/PolicyGovernance/PDF/wps3675.pdf (May 9, 2006).

Mbaku, J. M. (2003). Entrenching economic freedom in Africa. The Cato Journal, 23(2), 217. [Online] Available: http://www.questia.com/PM.qst?a=o\&docId=5009309811 (July 6, 2007).

Miles, M. A. (2006). Trade and justice; Marc A. Miles reviews Fair Trade for all: how trade can promote development. Harvard International Review, 28(2), 78. [Online] Available: http://www.questia.com/PM.qst?a=o\&d=501613584 (July 6, 2007).

National Development Planning Commission. (2006). Growth and poverty reduction strategy paper (GPRS II) (2006-2009). Washington, D. C.: World Bank. [Online] Available: http://siteresources.worldbank.org/INTPRS1/Resources/GhanaCostingofGPRS_2\%28Nov-2005\%29.pdf (June 13, 2007).

OECD. (2010). Competitiveness and private sector development: Egypt 2010. Business climate development strategy. Paris: OECD Publishing.

OSCE. (2006). Best-practice guide for a positive business and investment climate. Vienna: OSCE. [Online] Available: http://www.osce.org/eea/19768 (March 23, 2011).

Puplampu \& B. J. Berman. (2007). Critical perspectives in politics and socio-economic development in Ghana (pp. 153-175). Leiden, Netherlands: Brill. [Online] Available: http://www.questia.com/PM.qst?a=o\&d=109306612 (May 9, 2007).

Sachs, J. D., Mcarthur, J. W., Schmidt-Traub, G., Kruk, M., Bahadur, C., \& Faye, M., et al. (2004). Ending Africa's poverty trap. Brookings Papers on Economic Activity, (1), 117. http//dx.doi.org/10.1353/eca.2004.0018 
Siddiqi, M. (2006). Doing business climate improving ... in some countries. African Business. [Online] Available: http://findarticles.com/p/articles/mi_qa5327/is_326/ai_n29315170 (April 12, 2007).

Smallbone, D., and Wyer, P. (2006). Growth and development of the small business. In S. Carter and D. Jones-Evans (Eds.), Enterprises and small business. Principles, practices and policy (2 ed.), London: Pearson Education Limited, 100-125.

The International Monetary Fund and the World Bank. (2007). Accelerating development outcomes in Africa progress and change in the Africa Action Plan. Washington, D. C.: World Bank. [Online] Available: http://siteresources.worldbank.org/DEVCOMMINT/Documentation/21289631/DC2007-0008\%28E\%29-Africa ActionPlan.pdf (December 9, 2010).

The World Bank (n.d.). Pilot investment climate assessment. Improving the investment climate in India. Washington, D. C.: World Bank.

The World Bank. (2004). World development report 2005: A better investment climate for everyone. New York: World Bank \& Oxford University Press. [Online] Available: http://siteresources.worldbank.org/INTWDR2005/Resources/complete_report.pdf (June 7, 2006).

Versi, A., Nevin, T., \& Ford, N. (2005, July). Justice for Africa. African Business, 14. [Online] Available: http://www.questia.com/PM.qst?a=o\&d=5010023072 (July 6, 2007).

Table 1. Characteristics of the Sample

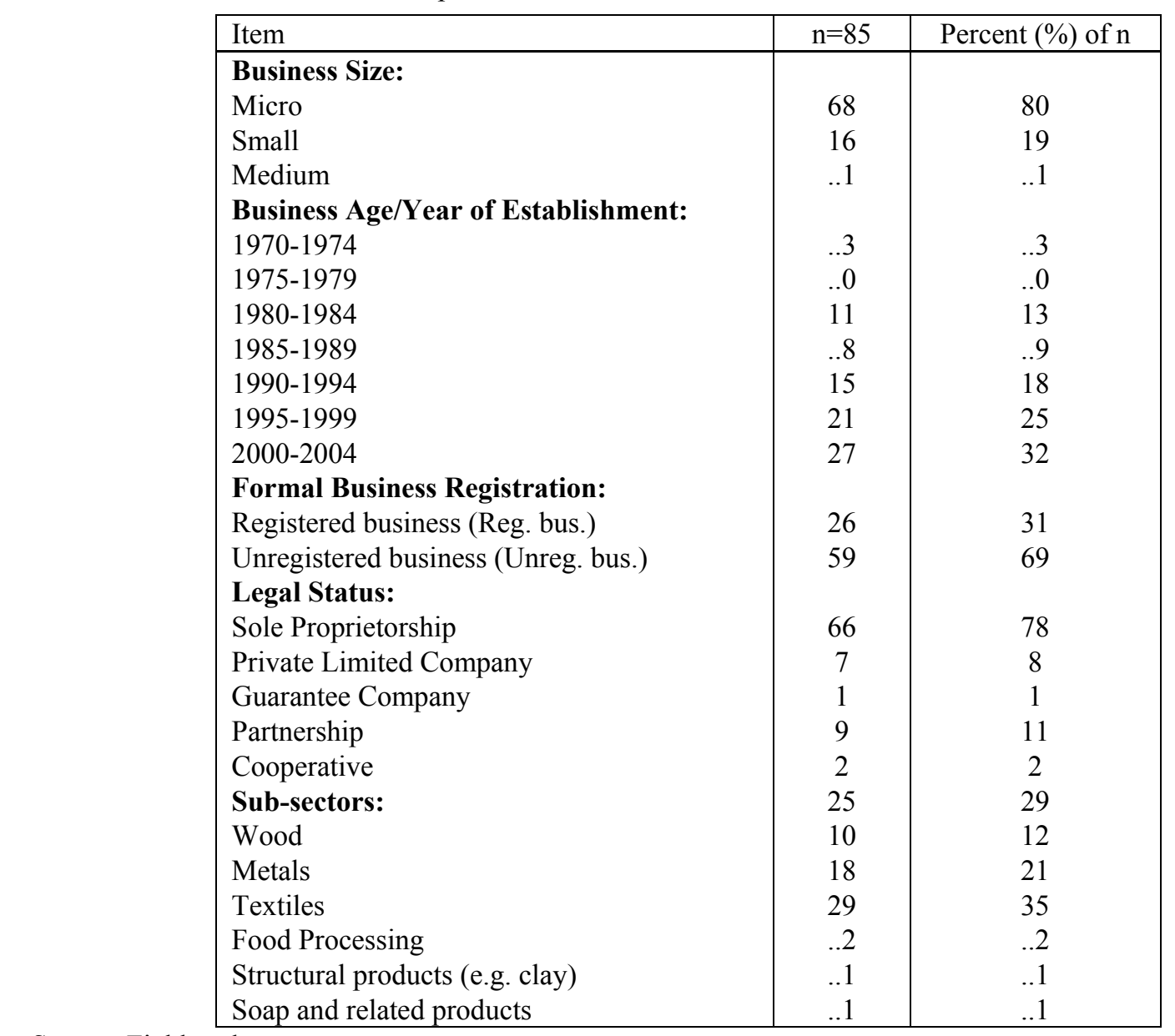

Source: Fieldwork 
Table 2. Access to Utilities

\begin{tabular}{|l|c|c|c|}
\hline Utility & Mean & S.D. & Usage (percent of n) \\
\hline Landline Telephone: & & & 17 \\
Affordability & 2.7 & 0.6 & \\
Quality & 3.6 & 0.5 & \\
Interruptions & 2.0 & 0.8 & 73 \\
Mobile Phone: & & & \\
Affordability & 3.2 & 0.7 & \\
Quality & 3.2 & 0.6 & 21 \\
& & & \\
Public Water Supply: & 3.1 & 0.8 & \\
Affordability & 3.3 & 0.9 & \\
Quality & 2.5 & 1.1 & \\
Interruptions & & & \\
& & & \\
Electricity: & 3.4 & 0.8 & \\
Affordability & 3.5 & 0.5 & \\
Quality & 2.2 & 0.6 & \\
Interruptions & & \\
\hline
\end{tabular}

Source: Field work

truptions

Note: there was no internet use by any of the enterprises in their business transactions. $(n=85)$

Table 3. Connection of business premise to public water supply system

\begin{tabular}{|l|c|}
\hline Sub-sector & $\begin{array}{c}\text { Percentage of MSMEs having water } \\
\text { supply at premise }\end{array}$ \\
\hline Wood & 20 \\
Metal & 10 \\
Textiles & 5 \\
Food & 28 \\
Structural (e.g. blocks, bricks, etc) & 100 \\
Soap and related products & 100 \\
\hline
\end{tabular}

Source: Fieldwork

Table 4. Access to business and technological support services

Note: $\mathrm{n}=85$

\begin{tabular}{|l|c|c|}
\hline Utility & Mean & S.D. \\
\hline Quality of service & 2.3 & 0.7 \\
Affordability of service & 1.3 & 0.5 \\
Frequency of use of service & 2.1 & 1.1 \\
\hline
\end{tabular}

Table 5. Public service acquisition and taxation

\begin{tabular}{|c|c|c|}
\hline Items & Mean & S.D. \\
\hline Delay in service provision: & & \\
\hline Landline telephone & 1.5 & 1.1 \\
\hline Water & 1.6 & 0.7 \\
\hline Electricity & 2.2 & 1.3 \\
\hline Construction permit & 3.0 & 2.3 \\
\hline $\begin{array}{l}\text { Operating license/business registration } \\
\text { Taxation: }\end{array}$ & 1.7 & 0.9 \\
\hline $\begin{array}{l}\text { Taxation: } \\
\text { Type of payment made to official revenue collection institutions }\end{array}$ & 5.6 & 26 \\
\hline $\begin{array}{l}\text { Iype of payment made to official revenue collection institutions } \\
\text { Affordability of amount paid }\end{array}$ & $\begin{array}{l}3.0 \\
3.6\end{array}$ & 0.7 \\
\hline Time expenditure per week by senior management & 1.2 & 0.4 \\
\hline Consistency and predictability of tax interpretations & 2.3 & 0.9 \\
\hline
\end{tabular}

Source: fieldwork 
Table 6. Access to bank credit

\begin{tabular}{|l|c|c|}
\hline Finance & Mean & S.D. \\
\hline Loan amount in Cedis & 5.5 & 2.2 \\
Loan repayment period & 1.6 & 0.8 \\
Interest rate & 4.4 & 1.7 \\
Type of collateral required & 2.5 & 1.7 \\
\hline
\end{tabular}

Source: Field work

Note: $n=85$. Successful applications within last two years as percent of $n=26$

\section{Appendix: Questionnaire}

\section{QUESTIONNAIRE FOR FIRM-LEVEL INTERVIEW \\ (Strict confidentiality of all information is assured)}

\section{Control Information}

Name of firm: Name of interviewee:

Gender: 1. Male 2. Female id_code:

Address: Year of establishment:

Name of City/town: Date of interview:

Name of interviewer:

Please answer all questions in relation to this enterprise (in this town/city).

\section{General Information}

1. Is your business registered?

a) Yes

b) No

2. What is the current legal status of your business?
a) Sole proprietorship
b) Private limited company
c) Public company
d) Guarantee Company
e) Partnership
f) Cooperative
g) Other (specify)

3. What is your main line of activity or operation? Manufacture of:
a) wood products
b) metal products
c) leather products
d) textiles
e) food processing
f) clay $\&$ related products
g) chemical (soap \& related products)
h) other (specify) 
4. a) What is the total number of persons currently engaged in this establishment?

\begin{tabular}{|l|l|l|l|l|l|l|l|}
\hline & $\mathbf{1 - 5}$ & $\mathbf{6 - 1 0}$ & $\mathbf{1 1 - 1 5}$ & $\mathbf{1 6 - 2 0}$ & $\mathbf{2 1 - 2 5}$ & $\mathbf{2 6 - 3 0}$ & $\mathbf{3 1}$ and above \\
\hline 1. Apprentices & & & & & & & \\
\hline 2. Part-time & & & & & & & \\
\hline 3. Full-time & & & & & & & \\
\hline 4. Seasonal/casual & & & & & & & \\
\hline
\end{tabular}

b) Specify business size based on response to Q 4 .
i) Micro
ii) Small
iii) Medium
iv) Large

\section{Investment Climate Measures}

\section{(I) Infrastructure Service Provision}

5. Does your firm utilise any of the following public (government) services?

\begin{tabular}{|l|l|l|l|}
\hline Utility & YES & NO & Reasons/Comments for not using service \\
\hline Landline telephone connection & & & \\
\hline Mobile phone connection & & & \\
\hline Water & & & \\
\hline Electricity & & & \\
\hline Internet/Email & & & \\
\hline
\end{tabular}

If $N O$ to all in $Q 14$ above, continue from $Q 18$

6. How will you rate the affordability of the services for a firm like yours?

$$
\begin{aligned}
& 1=\text { Not Very Expensive } \quad 2 \text { = Not Expensive } \quad 3 \text { = Moderate price } \\
& 4=\text { Expensive } \quad 5=\text { Very Expensive }
\end{aligned}
$$

\begin{tabular}{|l|l|l|l|l|l|}
\hline Utility & $\mathbf{1}$ & $\mathbf{2}$ & $\mathbf{3}$ & $\mathbf{4}$ & $\mathbf{5}$ \\
\hline Landline telephone connection & & & & & \\
\hline Mobile Phone connection & & & & & \\
\hline Water supply & & & & & \\
\hline Electricity & & & & & \\
\hline Internet/Email & & & & & \\
\hline
\end{tabular}

7. How will you rate the quality (breaks, voltage level, etc.) of the provision of the following services from the public grid?

$$
\begin{aligned}
& 1=\text { Very low quality } \quad 2=\text { Low quality } \quad 3=\text { Quality } \\
& 4=\text { High quality } \quad 5=\text { Very high quality }
\end{aligned}
$$

\begin{tabular}{|l|l|l|l|l|l|}
\hline Utility & 1 & 2 & 3 & 4 & 5 \\
\hline Landline telephone service & & & & & \\
\hline Mobile phone service & & & & & \\
\hline Water supply & & & & & \\
\hline Electricity supply services & & & & & \\
\hline Internet/Email & & & & & \\
\hline
\end{tabular}


8. For the past year how often, on the average, did your firm experience interruptions/breaks in service provision?

\begin{tabular}{|l|c|l|l|l|l|}
\hline Days in a Week & $\begin{array}{c}1 \\
\text { (Never) }\end{array}$ & $\begin{array}{c}2 \text { (Rarely i.e. } \\
\text { once/month) }\end{array}$ & $\begin{array}{c}3 \text { (Quite often i.e. } \\
\text { 2-5 times/month) }\end{array}$ & $\begin{array}{c}4 \text { (Often i.e. 6-10 } \\
\text { times/month) }\end{array}$ & $\begin{array}{c}5 \text { (Very often i.e. more } \\
\text { than } 10 \text { times/month) }\end{array}$ \\
\hline $\begin{array}{l}\text { Landline } \\
\text { telephone service }\end{array}$ & & & & & \\
\hline Water supply & & & & & \\
\hline $\begin{array}{l}\text { Electricity supply } \\
\text { services }\end{array}$ & & & & & \\
\hline Internet/Email & & & & & \\
\hline
\end{tabular}

9. Based on the experience of your establishment over the past years, what is the actual delay experienced (from the day you applied to the day you received the service or approval) and was a gift or informal payment asked for or expected to obtain each of the following?

\begin{tabular}{|l|c|c|c|c|c|c|c|}
\hline Waiting Time & $\begin{array}{c}1-2 \\
\text { weeks }\end{array}$ & $\begin{array}{c}\text { 3-4 } \\
\text { weeks }\end{array}$ & $\begin{array}{c}\text { 2-4 } \\
\text { Months }\end{array}$ & $\begin{array}{c}\mathbf{5 - 7} \\
\text { months }\end{array}$ & $\begin{array}{c}\mathbf{8 - 1 2} \\
\text { months }\end{array}$ & $\begin{array}{c}\text { 1 year } \\
\text { and } \\
\text { above }\end{array}$ & $\begin{array}{c}\text { Gift } \\
\text { expected? } \\
\text { Yes/No }\end{array}$ \\
\hline Landline telephone & & & & & & & \\
\hline Water connection & & & & & & & \\
\hline Electricity connection & & & & & & & \\
\hline Construction permit & & & & & & & \\
\hline An import license & & & & & & & \\
\hline $\begin{array}{l}\text { Operating } \\
\text { license/business } \\
\text { registration }\end{array}$ & & & & & & & \\
\hline
\end{tabular}

(II) Business Service, Technological \& Innovation Support

10. What qualification do you and employees have in relation to firm's operation?

\begin{tabular}{|l|l|l|l|l|l|l|l|l|}
\hline & None & $\mathbf{1 - 5}$ & $\mathbf{6 - 1 0}$ & $\mathbf{1 1 - 1 5}$ & $\mathbf{1 6 - 2 0}$ & $\mathbf{2 1 - 2 5}$ & $\mathbf{2 6 - 3 0}$ & $\begin{array}{c}\text { 31 and } \\
\text { above }\end{array}$ \\
\hline Illiterate & & & & & & & & \\
\hline Drop out & & & & & & & & \\
\hline Basic education & & & & & & & & \\
\hline Technical/vocational & & & & & & & & \\
\hline Secondary level & & & & & & & & \\
\hline Professional & & & & & & & & \\
\hline Tertiary & & & & & & & & \\
\hline
\end{tabular}

11. (a) Since the establishment of this firm, have you or any of your workers undergone 'further' training?
i) Yes
ii) No

(b) If YES, how many training have taken place within the last two year?

i) $1-3$

ii) $4-6$

iii) $7-10$

iv) 11 and above

(c) Type of training?

i) Technical

ii) Management

iii) Other (specify) 
12. Are you aware of the availability of business $\&$ technological support services in this locality (give examples like BACs,)?

a) Yes What are they

b) No (continue from Q 23)

13. How often does your firm utilise the services of the above-mentioned institutions for: product improvement, new product development, repairs, marketing issues, financial issues, management training, etc?

$1=$ Never $\quad 2$ = Occasionally (1-3 times in a year) $3=$ Quite Often (4-6 times in a year)

$4=$ Often (7-9 times in a year) $\quad 5=$ Very Often (above 9 times in a year)

\begin{tabular}{|l|l|l|l|l|l|}
\hline Copy institution name(s) from Q21 here & $\mathbf{1}$ & $\mathbf{2}$ & $\mathbf{3}$ & $\mathbf{4}$ & $\mathbf{5}$ \\
\hline & & & & & \\
\hline & & & & & \\
\hline & & & & & \\
\hline & & & & & \\
\hline
\end{tabular}

14. For which of the following does your establishment contact the institutions?

a) Product improvement

b) New product development

c) Tool/machine development or purchase

d) Market information (untapped market/potential market for products, etc)

e) Financial issues

f) Management assistance (e.g. advice \& training to enhance skills in performing management functions)

g) Other (specify)

15. How will you rate the service/product in terms of quality (importance and benefit to your establishment), and cost/affordability? Please rate on a scale of 1 to 3

Quality:

1=low quality

$2=$ quality

3=high quality

Affordability: $1=$ free of charge (no payment)

$2=$ not expensive $\quad 3=$ expensive

Copy institution names here from Q 21

\begin{tabular}{|l|c|c|c|c|c|c|}
\hline & $\mathbf{1}$ & $\mathbf{2}$ & $\mathbf{3}$ & $\mathbf{1}$ & $\mathbf{2}$ & $\mathbf{3}$ \\
\hline & & & & & & \\
\hline & & & & & & \\
\hline & & & & & & \\
\hline & & & & & & \\
\hline
\end{tabular}

16. How does your establishment come out with new products and business ideas?

a) Own innovation (in-house R\&D i.e. Research \& Development)

b) Learning from competitors (work \& pay)

c) Surveying competitors product for imitation/improvement own product

d) Further training (workshops, formal education, etc.)

e) Print Media

f) Others, including combinations of above (specify)

17. If $\mathrm{Q} 23$ (a), relating to $\mathrm{R} \& \mathrm{D}$, how often does the section come out with new products or improvement upon existing product?

a) Every 2-3 years (Very often)

c) Every 4-5 years (often) 
c) Every 6-7 years (quite often)

d) Above 7 years (rarely)

e) Not certain

\section{(III) Governance \& Regulations}

18. What payments do you make to government institutions?
a) None
b) Income tax
c) Artisan fee
d) Council levy
e) Income tax and artisan fee
f) Income tax and council levy
g) Artisan fees and council levy
h) Income tax, artisan fee and council levy

19. In a typical week, what percentage of senior management's time is spent in dealing with requirements imposed by tax inspectors etc?

a) $0-1 \%$ (Not time consuming)

b) $2-5 \%$

c) $6-10 \%$

d) Above $10 \%$

e) Do not deal with tax officials (Comments):

20. Do you make informal payments to tax officials to reduce tax rate or postpone assessment exercise.

a) Yes b) No

21. If YES in Q27, how does such payment affect your business operations?

a) Increase profit margin. comments:

b) Decrease profit margin. comments:

c) No effect on profit margin. comments:

22. "In general, tax officials' interpretations of regulations affecting my establishment are consistent and predictable." To what extent do you agree with this statement?
a) Disagree
b) Quite agree
c) Agree
d) Not certain (comment):

23. Based on the financial ability of a firm like yours how will you rate the tax amount you pay?
a) Very low
b) Low
c) Moderate
d) High
e) Very high

24. When establishment in your industry do business with the government, how much of the contract value is expected in gifts or informal payments to secure the contract?

a) $\%$

b) Not certain (reason): 


\section{(IV) Finance}

25. Please identify the contribution over the last 2 years of each of the following sources of financing for your establishment's working capital i.e. inventories, accounts receivables, and cash; and new investments i.e. new land, buildings, machinery and equipment.

Sources of Funds last 2 years:

$$
(\%)
$$

Internal funds/retained earnings

Local commercial banks (loan, overdraft)

Foreign-owned commercial banks

Trade Credit (supplier or customer credit)

Family, friends

Leasing arrangement

Special development financing or other

State services

Informal sources (e.g. money lenders)

Other (please specify)

26. Do you have an overdraft facility or line of credit/loan from your bank?

$\begin{array}{lll}\text { a) Yes (continue from Q 36) } & \text { b) No }\end{array}$

27. If NO, have you made any effort to secure an overdraft facility or credit/loan?

$\begin{array}{ll}\text { a) Yes } & \text { b) No }\end{array}$

28. If YES to Q34 above, why did the application not go through?
a) Inadequate collateral
b) High interest rate
c) Short repayment period
d) Bureaucratic \& procedural factors
e) No guarantors
f) High processing fees
g) Small size of loan
h) Other, including combinations of above (specify)

29. For the most recent loan or overdraft:

i) a) When was this financing approved (year)?
b) Did the financing require collateral or a deposit?
i) Yes
ii) No

c) If YES what was the type of collateral?
i) Land or building
ii) Machinery
iii) Intangible assets (accounts receivable, inventory)
iv) Personal assets of owner/manager (e.g. car)?
v) Guarantor(s)
vi) Other (specify)

ii) What is the loan's rate of interest?
a) $0-5 \%$
b) $6-10 \%$ 

c) $11-15 \%$
d) $16-20 \%$
f) $21-25 \%$
g) $26-30 \%$
h) Above $30 \%$

iii. What is the duration of the loan (Years or months)?

a) Less than 1 year

b) 1 year

c) 2 years

d) 3 years

e) 4 years

f) 5 years

g) More than 5 years

30. Are you satisfied with repayment period of loan?
a) Yes
b) No

iv. Are you satisfied with size of loan?
a) Yes
b) No (reason):

v. Loan Amount in Cedis

What would you recommend to be done to encourage firms like yours to expand to enter other markets in the country?

\section{THANK YOU.}

